\title{
DEFINICJE CZĄSTKOWE W PRAWIE
}

\author{
Pamięci Profesora Stanistawa Czepity
}

\section{UWAGI WSTĘPNE}

Przedmiotem prezentowanego artykułu są legalne definicje cząstkowe, a więc $\mathrm{z}$ jednej strony definicje o określonej strukturze logicznej, z drugiej zaś - definicje właściwe aktom prawnym i ich specyficznemu językowi. Każdy z powołanych aspektów z osobna stanowi interesujące pole do badań, ale dopiero ich połączenie umożliwia dostrzeżenie pewnych detali, których znaczenie okazuje się doniosłe zarówno dla teorii, jak i dla praktyki.

\section{KONCEPCJA DEFINICJI CZĄSTKOWYCH}

\section{U źródeł koncepcji definicji cząstkowych}

Za pierwszego, który zwrócił uwagę na istnienie pojęć niedających się określić za pomocą definicji równościowych, uważa się Rudolfa Carnapa ${ }^{1}$. W pracy Testability and Meaning zauważa on, że dla terminów takich, nazwanych później dyspozycyjnymi, musi zostać znaleziony inny sposób definiowania, który odpowiednio odda ich znaczenie ${ }^{2}$. Dla objaśnienia swoich twierdzeń Carnap posługuje się definicją pojęcia „rozpuszczalny w wodzie”, wskazując, że pojęcia tego nie sposób zdefiniować równościowo ${ }^{3}$.

W następującej definicji:

D1 Przedmiot jakiś jest rozpuszczalny w wodzie zawsze i tylko, jej̇eli przedmiot ten tworzy $z$ woda mieszanine jednorodna (roztwór),

kolejne oznaczenia zostały przyporządkowane jej poszczególnym elementom w sposób następujący:

Lx-przedmiot $x$ jest rozpuszczalny $w$ wodzie;

$W x, t$-przedmiot $x$ zostat $w$ dowolnej chwili $t^{4}$ wtożony do wody;

$O x, t$ - przedmiot $x$ w chwili t tworzy z woda roztwór ${ }^{5}$.

1 W. Patryas, Definiowanie pojęć prawnych, WN UAM, Poznań 1997, s. 73.

${ }^{2}$ R. Carnap, Sprawdzalność i znaczenie, w: idem, Filozofia jako analiza języka nauki, PWN, Warszawa 1969, s. 98-99.

3 Ibidem.

4 Przez sformułowanie „w dowolnej chwili $t$ ” należy rozumieć „kiedykolwiek”.

${ }_{5}$ T. Pawłowski, Tworzenie pojęć $i$ definiowanie $w$ naukach humanistycznych, PWN, Warszawa 1978 , s. $119-120$. 
Sformułowana wyżej definicja może być przeto odczytana w dwojaki sposób. Pierwsze jej rozumienie wygląda następująco:

\section{D2 $L x \equiv(t)[W x, t \rightarrow O x, t]$.}

Prawą stronę równoważności stanowi zdanie warunkowe (implikacja) $W x, t \rightarrow O x, t$. Zdanie takie jest prawdziwe, gdy jego poprzednik jest fałszywy lub następnik prawdziwy. Definicja daje rezultaty zgodne z oczekiwaniami, kiedy możliwe jest przeprowadzenie testu sprawdzajacego $W x$, $t$. Niech rozważone zostaną dwa przykłady, w których to zmienna $x$ raz reprezentować będzie przedmiot, o którym powszechnie wiadomo, że jest rozpuszczalny w wodzie (sól kuchenna), a za drugim razem - przedmiot, o którym wiadomo, że jest w wodzie nierozpuszczalny (zapałkę). W pierwszym przypadku na mocy definicji orzeczone zostanie, że sól kuchenna jest rozpuszczalna w wodzie, ponieważ po zanurzeniu tworzy ona z rozpuszczalnikiem roztwór; w drugim przypadku definicja każe przyjąć nierozpuszczalność w wodzie drewnianej zapałki, ponieważ po wykonaniu tego samego testu otrzymamy rezultat przeciwny zapałka nie stworzy z wodą roztworu'.

Jak wskazano, w obu powyższych przypadkach wykonano test sprawdzający $W x$,t. Jeśli jednak założymy niemożność wykonania owego testu (przyjmiemy, że $W x, t$ jest zawsze fałszywe), na mocy definicji implikacji zdanie warunkowe stanowiące prawa stronę definicji D2 będzie zawsze prawdziwe, co pociagnie za soba prawdziwość $L x$. Definicja ta każe przyjać, że wszystko to, co nie zostało kiedykolwiek zanurzone w wodzie, jest w niej rozpuszczalne tylko ze względu na niemożliwość wykonania testu $W x, t$ - także w odniesieniu do substancji, o których powszechnie wiadomo, że są w wodzie nierozpuszczalne. Powyższe rozważania doprowadziły do rezultatu nietrafnego. Definicja o budowie D2 nie nadaje się do zdefiniowania pojęcia rozpuszczalności w wodzie ${ }^{7}$ i innych pojęć o podobnych właściwościach logicznych.

Problemy w przypadku definicji D2 pojawiły się, gdy założono niemożliwość wykonania testu sprawdzającego opisanego $W x, t$, ponieważ wykonanie owego testu stanowiło warunek rozpuszczalności. Dalsze rozważania będa więc prowadzone po przekształceniu definicji D2 w taki sposób, aby zagwarantować wykonanie testu $W x, t$ :

$$
\text { D3 } L x \equiv(t)[W x, t \cdot O x, t] \text {. }
$$

Definicja D3 jest drugą możliwą interpretacją przytoczonej na początku definicji D1. Przez zastapienie implikacji koniunkcją zapewnione zostaje bezwarunkowo wykonanie testu $W x, t$. Fałszywość bowiem zdania $W x, t$ pociaga za sobą fałszywość koniunkcji, a fałszywość tej ostatniej - konieczność uznania $L x$ za fałszywe. W takim przypadku, jeżeli założymy niemożliwość zanurzenia w wodzie, służącej za przykład ciała nierozpuszczalnego, drewnianej zapałki

\footnotetext{
${ }^{6}$ Ibidem, s. 120.

7 Ibidem, s. 120-121.
} 
(zapałka została wcześniej spalona), nie otrzymamy już zaskakującego rezultatu stanowiącego o rozpuszczalności owej zapałki. Rozwiązana zostaje kwestia uznawania za rozpuszczalne w wodzie substancji, o których powszechnie wiadomo, że są w wodzie nierozpuszczalne, z powodu niemożliwości przeprowadzenia opisanego wcześniej testu sprawdzającego ${ }^{8}$.

Pomimo to definicja D3 jest również obarczona wadą nieadekwatności. Przy założeniu niemożliwości wykonania testu $W x, t$, tak sformułowana definicja będzie prowadziła do uznania za nierozpuszczalne w wodzie substancji, o których powszechnie wiadomo, że sa w niej rozpuszczalne, tylko na podstawie fałszywości zdania $W x, t$, ponieważ fałszywość tego zdania implikuje fałszywość całej koniunkcji (nawet jeśli zdanie $O x, t$ jest prawdziwe), a jej fałszywość - fałszywość $L x$. Odwołując się do przykładu soli kuchennej - jeśli założymy niemożliwość zanurzenia jej w wodzie (została ona wcześniej zniszczona), na gruncie definicji D3 należało będzie przyjać, że sól taka jest w wodzie nierozpuszczalna, co jest niezgodne ze stanem rzeczywistości.

Niemożliwość sformułowania definicji pojęcia „rozpuszczalny w wodzie” według określonych wyżej schematów równościowych spowodowana jest tym, iż pojęcie to ma dyspozycyjny charakter, a więc jest definiowalne tylko czastkowo. Carnap rozwiązał ten problem, wprowadzając konstrukcję tzw. definicji redukcyjnych. Dzięki ich nierównościowemu charakterowi usunięta zostaje wada tworzenia twierdzeń niezgodnych z rzeczywistościa - definicja przestaje odnosić się do sytuacji, w których niemożliwe jest wykonanie zawartego w niej testu sprawdzającego. Wiąze się to z pewnymi kosztami - definicje takie nie orzekaja w odniesieniu do wszystkich elementów zakresu, a jedynie wobec takich, które wskazany w definicji warunek spełniaja.

\section{Rozwój koncepcji definicji cząstkowych i rodzaje definicji cząstkowych}

Carnap do wprowadzania terminów dyspozycyjnych zaproponował zdania redukcyjne, które później zaczęto określać mianem definicji redukcyjnych. Ideę tych ostatnich uogólniono następnie do kategorii definicji cząstkowych, a same definicje redukcyjne stały się szczególną odmianą wyróżnionej klasy ${ }^{9}$. Stwierdzono także, że terminy teoretyczne (do których należą terminy dyspozycyjne) i terminy nieostre maja takie same właściwości logiczne ${ }^{10}$, a więc te ostatnie również można definiować za pomocą definicji cząstkowych. Definicje czastkowe zostały uznane za stworzone wręcz do określania pojęć nieostrych, a pojęcia owe zaczęto utożsamiać z pojęciami definiowalnymi tylko cząstkowo ${ }^{11}$.

8 Ibidem, s. 121 i 122.

9 W. Patryas, Definiowanie..., s. 73.

${ }^{10}$ Ibidem, s. 73; zob. też: M. Przełęcki, Z semantyki pojęć otwartych, w: Semiotyka polska 1894-1968, Warszawa, PWN, 1971, s. 332.

11 W. Patryas, op. cit., s. 73; zob. też: M. Przełęcki, W sprawie terminów nieostrych, „Studia Logica” 8, 1958, s. 314. 
Definicja cząstkowa w swej najprostszej formie składa się z pary zdań, gdzie pierwsze podaje warunek wystarczający, a drugie - warunek konieczny przynależności jakiegoś elementu do zakresu definiowanego wyrażenia. Można ją przedstawić według schematu:

D4 $R x \rightarrow P x, \sim S x \rightarrow \sim P x$.

Można ją też zapisać $\mathrm{w}$ prostszej formie z pominięciem negacji (gdzie aby definicje te były równoważne, warunkiem koniecznym jest to, aby zakresy denotacji predykatów $T$ oraz $S$ wykluczały i dopełniały się ${ }^{12}$ ):

D5 $\quad R x \rightarrow P x, T x \rightarrow \sim P x$

- w takim przypadku definicja będzie podawała dwa warunki wystarczające. Przy określonych założeniach (które muszą odpowiadać charakterystyce definiowanego pojęcia) i po odpowiednich przekształceniach możemy otrzymać inne jeszcze warianty definicji cząstkowych ${ }^{13}$. Jeśli przyjąć, że wyrażenie $\sim S$ albo wyrażenie $T$ oznacza warunek nieistniejący, otrzymane zostanie w obu przypadkach: $R x \rightarrow P x$, czyli schemat prostych zdań warunkowych. A jeśli ponadto przyjmiemy, że $R x \equiv W x, t \cdot O x, t$, to otrzymamy schemat definicji redukcyjnych jednostronnych $(W x, t \rightarrow[O x, t \rightarrow L x])$. Dla zbudowania schematu definicji redukcyjnych obustronnych potrzebne sa dodatkowe założenia, które wyrażone przez drugą definicję redukcyjną jednostronna o postaci $W x, t \rightarrow[L x \rightarrow O x, t]$, wraz z pierwszą dadza rezultat $W x, t \rightarrow[L x \equiv O x, t]$.

Ciekawą rzecz można zauważyć przy założeniu, że wyrażenie $\sim S$ albo wyrażenie $T$ sa tożsame $\mathrm{z}$ wyrażeniem $\sim R$. W takim przypadku otrzymane będzie za każdym razem $R x \rightarrow P x, \sim R x \rightarrow \sim P x$. Te dwa zdania warunkowe sa przekształconą równoważnością mająca postać $P x \equiv R x$, która to najpierw rozłożona została na dwa zdania $P x \rightarrow R x, R x \rightarrow P x$, a następnie do pierwszego z tych zdań zastosowano prawo transpozycji i wykorzystano odpowiednie prawa rachunku kwantyfikatorów, otrzymując wyrażenie $\sim R x \rightarrow \sim P x$. Wspomniana wcześniej równoważność to definicja równościowa. Z powyższych rozważań wynika przeto, iż definicje równościowe są szczególnym przypadkiem definicji czastkowych ${ }^{14}$.

W tym miejscu warto zwrócić uwagę na jeszcze jedną kwestię. Na początku niniejszego podpunktu wskazane zostało, za Marianem Przełęckim i Wojciechem Patryasem, że terminy nieostre powszechnie utożsamia się z terminami definiowanymi tylko cząstkowo. Należy zgodzić się z tym poglądem. Co jednak z definicjami cząstkowymi? Czy za ich pomocą można definiować jedynie po-

${ }^{12}$ Dla poprawności przekształcenia definicji D4 w definicję D5 wystarczy słabszy warunek gdy zakresy $S$ i $T$ będa tylko przeciwne (zakres $T$ będzie podrzędny w stosunku do zakresu $\sim S$ ), ale wtedy definicje te nie będą sobie równoważne, a jedynie druga będzie wynikała z pierwszej. W przypadku takiego przekształcenia zwiększy się pas nieostrości definiowanego pojęcia.

${ }^{13}$ W. Patryas, op. cit., s. 74

${ }^{14}$ Ibidem, s. 74. 
jęcia nieostre? Takie założenie wydaje się błędne, ponieważ nieostrość pojęcia może zostać wyłączona przez cechy zbioru, który przebiega zmienna występująca w tej definicji. Niech dana będzie definicja $R x \rightarrow P x$, gdzie zbiór $P$ zawiera $x$ będące liczbami mniejszymi niż 2 . Pomimo tak sformułowanej definicji możliwe jest, by pojęcie przez nią zdefiniowane było ostre - zbiór, który przebiega definicja, może okazać się ze swej natury zbiorem liczb naturalnych ${ }^{15}$. W takim wyjątkowym przypadku definicja odnosić się będzie wyłącznie do liczby „1”.

Pierwszym z omawianych rodzajów definicji cząstkowych są tzw. obustronne definicje redukcyjne, zwane niekiedy definicjami warunkowymi. Przyjmuja one następującą postać:

D6 (t) $\{W x, t \rightarrow[L x \equiv O x, t]\}$.

Taka forma definicji pozwala uniknąć błędów, które pojawiały się przy rozważaniach na podstawie definicji D2 i D3, ponieważ definicje zbudowane zgodnie z ową formuła nie dostarczają kryteriów dla dowolnych elementów, lecz jedynie dla takich, które spełniają warunek $W x, t$. Na podstawie tej definicji można stwierdzić, że przedmioty spełniające warunek $O x, t$ (oraz jednocześnie warunek testowy) należą do zakresu $L x$, a przedmioty niespełniające warunku $O x, t$ (spełniające jednak wciąż warunek testowy) należą do zakresu $\sim L x^{16}$.

Kolejnym rodzajem definicji czastkowych są jednostronne definicje redukcyjne, różniące się od obustronnych definicji redukcyjnych tym, że podają one dla danych elementów spełniających warunek testowy jedynie kryterium pozytywne albo jedynie kryterium negatywne. Definicje takie moga przyjmować odpowiednio dla powyższych kryteriów formy:

D7 (t) $\{W x, t \rightarrow[O x, t \rightarrow L x]\}$

albo

D8 (t) $\{A x, t \rightarrow[D x, t \rightarrow \sim L x]\}^{17}$.

Należy zwrócić uwagę, że definicje zbudowane zgodnie z powyższymi schematami łącznie nie zawsze będą określały zakres definiowanego pojęcia w pełni. Aby tak było, elementy zbioru, który przebiegałaby występujące w definicjach zmienne, musiałyby spełniać dodatkowe wymogi: każdy element zbioru musiałby spełniać zarazem wymogi $W x, t$ i $O x, t$ bądź zarazem wymogi $A x, t$ i $D x, t^{18}$ - jest to przykład wspomnianej wcześniej wyjątkowej sytuacji, w której nieostrość definiowanego pojęcia zostanie wyłączona przez cechy elementów zbioru.

\footnotetext{
${ }^{15}$ Przyjmuje się w niniejszej pracy, że $\mathrm{N}=\mathrm{R}_{+}$; do zbioru liczb naturalnych nie zalicza się „0”.

${ }_{16}$ T. Pawłowski, op. cit., s. 123-124.

17 Ibidem, s. $124-125$.

18 Ibidem, s. 125.
} 
Inna jeszcze odmianą definicji czastkowych sa proste zdania warunkowe, mające postać:

D9 $\quad W x \rightarrow P x$

albo

D10 $E x \rightarrow \sim P x$,

które, podobnie jak definicje redukcyjne jednostronne, dla określonych elementów dostarczają odpowiednio jedynie kryterium pozytywnego albo jedynie kryterium negatywnego. Innym podobieństwem do definicji redukcyjnych jednostronnych jest to, że powyższe zdania warunkowe łącznie moga w pełni określać definiowane pojęcie, ale tylko w wyjątkowej sytuacji - gdy zbiór, który przebiegać będzie występująca w definicji zmienna, składać się będzie jedynie z elementów spełniających warunek $W$ bądź warunek $E^{19}$; jeśli brak będzie elementów niespełniających żadnego z wymienionych kryteriów, brak będzie również pasa nieostrości, a zatem jest to kolejny przykład wyłaczenia nieostrości pojęcia przez cechy samych elementów zbioru.

Ostatnim omawianym w niniejszej pracy wariantem definicji cząstkowych są cząstkowe definicje probabilistyczne. Mogą on przybrać prostą postać:
D11
$(R, P)=k$
$(S, \sim P)=l, \quad$ gdzie $0<k, l<1^{20}$.

Takie definicje nie określaja kategorycznie, choćby cząstkowo, zakresu danego pojęcia, ale stwierdzaja jedynie, jakie jest prawdopodobieństwo, że określony element pod ten zakres podpada ${ }^{21}$. Przynależność definicji probabilistycznych do grupy definicji cząstkowych uwidacznia się w szczególnej sytuacji - gdy prawdopodobieństwa $k$ i $l$ są równe 1; definicja o takiej charakterystyce utraci swój probabilistyczny charakter i będzie ją można przedstawić w postaci: $R x \rightarrow P x, T x \rightarrow \sim P x$, która to postać stanowi schemat definicji cząstkowych w ich podstawowym kształcie ${ }^{22}$.

Scharakteryzowane powyżej rodzaje definicji cząstkowych są ich najczęściej wymienianymi przypadkami w różnego rodzaju opracowaniach dotyczacych definiowania w naukach humanistycznych, ze względu na najpowszechniejsze zastosowanie w owych naukach tych właśnie rodzajów definicji cząstkowych $^{23}$. Z tego samego powodu rzeczone rodzaje definicji cząstkowych zostały ujęte w niniejszym artykule.

\footnotetext{
19 Ibidem, s. 126.

${ }^{20}$ W. Patryas, op. cit., s. 84.

21 T. Pawłowski, op. cit., s. 127.

${ }^{22}$ W. Patryas, op. cit., s. 84.

${ }^{23}$ T. Pawłowski, op. cit., s. 127.
} 


\section{ZASTOSOWANIE DEFINICJI CZĄSTKOWYCH W PRAWIE}

\section{Definicje legalne a język prawny}

Andrzej Malec wskazuje na wyróżnione przez Bronisława Wróblewskiego trzy rodzaje wyrażeń tworzących język prawny:

1) wyrażenia wprowadzone przez prawodawcę;

2) wyrażenia zapożyczone, których znaczenie zostało zmienione przez prawodawcę;

3) wyrażenia zapożyczone, których znaczenie pozostało niezmienione ${ }^{24}$. Tak rozumiany język prawny Wróblewski nazywa językiem prawnym sensu largo, wyróżnia także język prawny sensu stricto złożony jedynie z wyrażeń z grupy pierwszej i drugiejej.

Obecnie występują tendencje do poszerzania zakresu pojęcia „definicja” i obejmowania nim nawet cząstkowej charakterystyki sposobu użycia danego wyrażenia ${ }^{26}$. Najbardziej charakterystycznym przykładem tego zjawiska jest oczekiwanie ze strony twórcy tekstu, że sam odbiorca jedynie poprzez kontekst ${ }^{27}$, w którym zostało umieszczone dane wyrażenie, odkoduje kluczowe fragmenty jego znaczenia. Przy takim rozumieniu definicji okazuje się, że wyrażenia, które Wróblewski zaliczył do trzeciej grupy, również są w języku prawnym $\mathrm{w}$ jakiś sposób zdefiniowane. W takim przypadku do trzeciej grupy zaliczymy nie wyrażenia niezdefiniowane przez prawodawcę, gdyż takie w tekstach aktów normatywnych nie występuja, a jedynie takie wyrażenia, których charakterystyka podana w języku prawnym będzie wyznaczać dokładnie takie samo ich znaczenie, jak charakterystyka takich samych wyrażeń w języku etnicznym, z którego ustawodawca korzysta przy tworzeniu języka prawnego. Należy rozważyć, czy taka sytuacja jest w ogóle możliwa, skoro w praktyce język polski i prawny moga mieć różne słowniki, a słowa należące do każdego z tych słowników korespondują ze soba, oddziałując wzajemnie na swoje znaczenia, języki te spełniaja różne role: jeden służy wyrażaniu i wymianie myśli jego użytkowników, drugi zaś - wyrażeniu norm ustanowionych przez prawodawcę, jeden był kształtowany spontanicznie, drugi jest językiem sztucznym. Powołane przykłady nie wyczerpuja całego katalogu różnic pomiędzy językiem prawnym i powszechnym językiem polskim. Powstaje więc problem, czy mając na uwadze te wszystkie różnice,

${ }^{24}$ Językiem prawnym B. Wróblewski nazywa język, którego źródłem są przepisy prawne. Zob. idem, Język prawny i prawniczy, PAU, Kraków 1948.

${ }_{25}$ A. Malec, Zarys teorii definicji prawniczej, Philomath, Warszawa 2000, s. 17.

${ }^{26}$ Ibidem, s. 28.

${ }^{27}$ Słowa „kontekst” użyto w niniejszej pracy niejako z konieczności - wyrazem tym posługuje się sam prawodawca, np. w $§ 146$ ust. 2 załącznika do rozporządzenia Prezesa Rady Ministrów z 20 czerwca 2002 r. w sprawie „Zasad techniki prawodawczej”, Dz. U. 2016, poz. 283 (dalej jako: ZTP), odnosząc się raczej do otoczenia językowego danego wyrażenia, a nie do rozumienia pojęcia „kontekst”, jakie wynika z definicji wyrażenia „definicja kontekstowa”. Pomimo więc używania słowa kontekst, chodzi w powyższym fragmencie raczej o definicje przez postulaty niż o definicję kontekstowa. 
możliwe jest odnalezienie w obu językach wyrażeń równokształtnych znaczacych to samo.

Rozwiąanie jest pozytywne, taką kategorię stanowią wyrażenia synkategorematyczne. Wyrażenia takie nie mają samodzielnego znaczenia, ich sens wynika nie tyle ze znaczeń innych wyrazów tego samego języka, ile ze stosunków między nimi. Mimo że języki prawny i polski na różne sposoby będa charakteryzować takie wyrażenia, to rezultaty tych charakterystyk będą identyczne. Właśnie tę waską grupę wyrażeń można zaliczyć do trzeciej wyróżnionej przez Wróblewskiego grupy.

Aby stwierdzić kategorycznie, że w omawianych językach nie istnieje poza należącymi do opisanej wyżej grupy - żadna para jednobrzmiących wyrażeń, których znaczenia będą identyczne, należałoby przestudiować znaczenia wszystkich zwrotów obu języków we wszystkich możliwych kontekstach. Gdyby było to wykonalne (a nie jest), prawdopodobieństwo odnalezienia takiej pary wyrażeń byłoby bliskie zeru.

System prawa składa się głównie z wyrażeń skonstruowanych przez prawodawcę, będących novum w języku prawnym i etnicznym, oraz wyrażeń przejętych z języka powszechnego, których znaczenie zostało zmienione przez prawodawcę (chociażby przez umieszczenie w określonym kontekście). Wyrażenia języka prawnego sensu stricto wyraźnie więc przeważają wśród wszystkich wyrażeń języka prawnego - zwroty należące do trzeciej wyróżnionej przez Wróblewskiego grupy sa stosunkowo nieliczne. Ponadto dotychczasowe rozważania prowadzą do wniosków, że system prawny składa się z samych definicji, to znaczy sens każdego wyrażenia w języku prawnym jest wyłącznie zdeterminowany przez reguły tego języka. W dalszej części artykułu zostanie rozważony charakter tych definicji.

\section{Koncepcja definicji legalnych sensu stricto i sensu largo a definicje cząstkowe}

Jeszcze w 1956 r. Zygmunt Ziembiński, odnosząc się do aktów ustawodawczych, mianem definicji określał jedynie taki zwrot, który „wyraźnie i bezpośrednio informuje, jakie znaczenie wiązać należy z poszczególnymi użytymi przez normodawcę wyrażeniami”" Ze wskazanego zakresu wyłącza nawet powszechnie dziś uważane za definicje - definicje nawiasowe, określając je nazwami „wyrażenie paradefinicyjne”, „paradefinicja”29. Odnosząc się jednak do rozpowszechnionego użycia terminu „definicja”, należałoby uznać za definicję legalna każdy zbiór wyrażeń określających dane pojęcie występujące w systemie prawa. Niektóre spośród tych wyrażeń mają jednak wyraźnie odmienny charakter - nawet nieposiadający wiedzy prawniczej uznaja je za pełniące role definicji.

${ }^{28}$ Z. Ziembiński, $O$ zwrotach definicyjnych $w$ ustawodawstwie $P R L$, „Zeszyty Naukowe Uniwersytetu im. Adama Mickiewicza w Poznaniu” 1956, Zeszyt Specjalny, s. 61.

${ }^{29}$ Ibidem, s. 61 i 74. 
Cały zbiór definicji legalnych dzieli się na definicje sensu stricto i sensu largo $^{30}$. Malec uznaje definicje sensu stricto za wyrażenia wprowadzone przez prawodawcę w celu ustalenia znaczenia określonego zwrotu, a definicje sensu largo uznaje za nieposiadające tego przymiotu ${ }^{31}$. Kryterium istnienia celu określenia znaczenia wydaje się prima facie prowadzić do naturalnego podziału definicji. Okazuje się jednak, że nie zawsze jest użyteczne, ponieważ prowadzi do uznania za definicję sensu stricto definicji, o których mowa w $\S 146$ ust. 2 ZTP. Prawodawca bowiem, umieszczając określony zwrot w jakimś kontekście, może działać w celu (kontekstowego) zdefiniowania tego zwrotu ${ }^{32}$. Mimo że wydaje się, iż nie takie jest oryginalne rozumienie kryterium autora podziału, podział ten należy utrzymać, chociażby ze względu na jego intuicyjność i przydatność w rozważaniach podobnych niniejszym, a kryterium wybrać w inny sposób. Ostatecznie więc definicje legalne sensu stricto to te wyrażenia, których zasady tworzenia i wprowadzania do tekstów aktów prawnych określone są w § 146-153 ZTP ${ }^{33}$. Wyróżniają się one nie tylko tym, że sam ustawodawca nazywa je definicjami, wszystkie one charakteryzują się również powiązaniem ich definicyjnego charakteru z samą ich formą oraz wyraźnym wskazaniem zwrotu definiowanego. Natomiast definicje legalne sensu largo obejmuja wszystkie te wyrażenia, które na gruncie poprzednich rozważań uznane zostały za definicje legalne, definicje, których definicyjny charakter wynika ze struktury samego systemu prawnego oraz założeń o nim przyjętych ${ }^{34}$ i których zwrot definiowany może zarazem stanowić element wyrażenia definiującego w odniesieniu do innego zwrotu ${ }^{35}$.

Podział na definicje sensu stricto i sensu largo znajduje swoje dopełnienie w poszczególnych dyrektywach sformułowanych w ZTP. Ustanowione tam reguły dotyczące definiowania w tekstach aktów prawnych służyć mają nie tylko zachowaniu niesprzeczności systemu prawa, ale także jego przejrzystości i jednoznaczności używanych w języku prawnym zwrotów. Wyróżnione w powołanym zbiorze zasad tworzenia prawa sytuacje, w których istnieje obowiazek wprowadzenia definicji, mają charakter szczególnie wrażliwy ze względu na wartość zrozumiałości prawa. Definicje legalne wprowadzane do systemu prawa na podstawie dyrektyw zawartych w ZTP to definicje takich wyrażen, których treść zamierzoną przez ustawodawcę system prawa bez wprowadzenia definicji legalnej wyrażałby w sposób nieadekwatny.

${ }^{30}$ A. Malec, op. cit., s. 28 i 29.

${ }^{31}$ Ibidem, s. 29.

${ }^{32}$ Zob. ZTP - 1146 ust. 2 i dalsze części artykułu.

${ }^{33}$ Ibidem.

${ }^{34}$ System prawa jest spójny, niesprzeczny, a tworzacy go ustawodawca jest bytem racjonalnym.

${ }^{35}$ Choć oczywiście pojęcie definicji legalnych sensu largo obejmuje swym zakresem pojęcie definicji legalnych sensu stricto, przyjmuje się, że w dalszej części artykułu, ilekroć użyte zostanie określenie „definicje legalne sensu largo”, będzie się ono odnosiło jedynie do tych definicji legalnych, które nie są definicjami sensu stricto. 


\section{Legalne definicje cząstkowe jako definicje intrajęzykowe}

W systemie prawa występuja zarówno definicje metajęzykowe, jak i definicje intrajęzykowe ${ }^{36}$. Zgodnie ze stanowiskiem Malca pierwsza kategoria nadaje się do określania znaczeń dowolnych wyrażeń (np. predykatów), a za pomoca drugich możliwe jest określanie znaczenia jedynie samych nazw ${ }^{37}$. O definicjach cząstkowych Malec stwierdza, że są definicjami w języku przedmiotowym ${ }^{38}$. Należałoby więc nazwać je definicjami intrajęzykowymi, nie pozwala na to jednak - na gruncie przyjętych przez autora założeń - ustalenie, że definicje cząstkowe są definicjami predykatów ${ }^{39}$. Powstały dysonans Malec rozwiązuje, odmawiając definicjom cząstkowym zdolności do występowania $\mathrm{w}$ tekstach prawnych ${ }^{40}$, a na ich miejsce wprowadza definicje quasi-czastkowe ${ }^{41}$, które sa rodzajem definicji quasi-legalnych zdatnych do definiowania predykatów ${ }^{42}$.

Powyższy pogląd nie wydaje się trafny. Brak podstaw, aby stwierdzić, że definicje intrajęzykowe sa definicjami wyłącznie nazw. Po odrzuceniu tej tezy nie ujawniają się żadne niezgodności. Warunkiem sklasyfikowania określonej definicji jako intrajęzykowej jest jedynie operowanie przez nią językiem przedmiotowym ${ }^{43}$; odwoływanie się do innych kryteriów nie znajduje podstaw. Definicje cząstkowe zaś są wyróżniane ze względu na swoją strukturę logiczną; mogą one występować w dowolnym języku, także prawnym. Intrajęzykowe definicje legalne mogą być zatem definicjami cząstkowymi.

\section{KATEGORIA DEFINICJI CZĄSTKOWYCH A KONCEPCJE DEFINICJI LEGALNYCH}

\section{Definicje cząstkowe a Zasady techniki prawodawczej}

Wskazówek dotyczących formułowania definicji legalnych udziela sam prawodawca w ZTP. W § 146 ust. 1 ZTP ustanowiony został zamknięty katalog przesłanek zasadności tworzenia definicji w aktach normatywnych, z których to przesłanek musi być spełniona co najmniej jedna, aby sformułowanie definicji danego określenia było legitymowane. Warunkiem więc poprawności sformułowania definicji legalnej jest, aby występowała:

1) wieloznaczność określenia;

2) nieostrość określenia w sytuacji, gdy pożądane jest ograniczenie tej nieostrości;

3) brak powszechnej zrozumiałość danego określenia;

\footnotetext{
${ }^{36}$ W. Patryas, Elementy logiki dla prawników, Ars boni et aequi, Poznań 2002, s. 164-165.

${ }^{37}$ A. Malec, op. cit., s. 45.

${ }^{38}$ Ibidem, s. 50.

${ }^{39}$ Ibidem.

${ }^{40}$ Ibidem.

${ }^{41}$ Ibidem, s. 55.

${ }^{42}$ Ibidem, s. 52.

${ }^{43}$ W. Patryas, Elementy..., s. 164-165.
} 
4) potrzeba ustalenia nowego znaczenia danego określenia, ze względu na dziedzinę regulowanych spraw.

Pierwszy punkt należy uzupełnić o warunek z drugiego ustępu § 146 ZTP, który stanowi, że „jeżeli określenie wieloznaczne występuje tylko w jednym przepisie prawnym, jego definicję formułuje się tylko w przypadku, gdy wieloznaczności nie eliminuje zamieszczenie go w odpowiednim kontekście językowym".

Na gruncie poczynionych wyżej założeń można stwierdzić, że umieszczenie określenia w odpowiednim kontekście stanowi formę jego zdefiniowania. Definicje odtwarzane $\mathrm{z}$ kontekstu ${ }^{44}$ mogą być definicjami podajacymi wszystkie kryteria stosowalności dla tego wyrażenia, jednakże w przeważającej części będą miały charakter cząstkowy.

Gdy dla usunięcia wieloznaczności danego określenia nie jest wystarczające samo kontekstowe jego zdefiniowanie, konieczne będzie skonstruowanie definicji legalnej sensu stricto. W tym miejscu prawodawca nie odwołuje się w ogóle do wymaganej, czy choćby preferowanej, formy definicji; nie ma chyba jednak wątpliwości, że do ujednoznacznienia pojęcia może posłużyć zarówno definicja równościowa, jak i nierównościowa (choćby cząstkowa).

Druga przesłanką formułowania definicji legalnych jest występowanie niepożądanej przez prawodawcę nieostrości pojęcia. Definicje cząstkowe często pojawiają się jako definicje pojęć nieostrych. Nie oznacza to jednak ani tego, że aby wyeliminować nieostrość trzeba posłużyć się definicją równościowa, ani tego, że skoro pojęcie jest wyjściowo nieostre, można w stosunku do niego użyć wyłącznie definicji cząstkowej. Jeśli legislator, zgodnie z nakazem wyrażonym w § 146 ust. 1 pkt 2 ZTP, definiuje pojęcie nieostre i jednocześnie korzysta z formuły definicji cząstkowej, to dokonana czynność nie jest bezcelowa czy błędnie przeprowadzona, jeśli tylko pasy nieostrości definiowanego pojęcia zostaną ograniczone. Wskazuje na to samo brzmienie przepisu - pojawia się tam sformułowanie „ograniczenie nieostrości”, a nie „wyeliminowanie nieostrości”. Jeśli jednak przyjmiemy, że w zakresie pojęcia „ograniczenie nieostrości” mieści się także jej całkowite wyeliminowanie, to możliwe jest posłużenie się definicją równościową dla nadania definiowanemu pojęciu ostrego charakteru.

Nie ma chyba wątpliwości, że zarówno formułę definicji równościowej, jak i cząstkowej można zastosować w przypadku wystapienia pozostałych dwóch przesłanek. Definicje obu rodzajów pozwolą na osiagnięcie zamierzonego celu - usunięcie niezrozumiałości pojęcia lub nadanie mu nowego znaczenia, nawet jeśli przy zastosowaniu definicji cząstkowej zakres tego pojęcia nadal będzie nieostry.

W $§ 151$ ZTP prawodawca określa możliwe sposoby formułowania definicji. Wskazuje na stylizacje: semantyczna („Określenie „a” oznacza b.”45), słownikową („Określenie „a” znaczy tyle co wyrażenie „b”.”46) oraz przedmiotowa

${ }^{44}$ Definicje takie zostały zaliczone w niniejszym artykule do kategorii definicji legalnych sensu largo. Zob. wyżej, przyp. 28.

${ }^{45} \S 151$ ust. 1 ZTP.

${ }^{46} \S 151$ ust. 1 ZTP. 
(z użyciem spójnika „jest to” $\left.{ }^{47}\right)^{48}$, z których pierwsza jest najbardziej, a ostatnia najmniej preferowana. Dwie pierwsze stylizacje zmuszają do tworzenia definicji w języku drugiego stopnia; na gruncie przedstawionych wyżej rozważań wiadomo więc, że nie zostaną utworzone przy ich użyciu definicje cząstkowe. Inaczej jest z trzecia z proponowanych przez prawodawcę formuł - wyrażenia „,jest to”, „są to” moga występować zarówno w definicjach równościowych, jak i cząstkowych - w przypadku tych ostatnich należy jednocześnie zaznaczyć, że zakres pojęcia wyznaczono cząstkowo, używając odpowiedniego zwrotu ${ }^{49}$. Proponując taka stylizację, prawodawca dopuszcza tym samym tworzenie definicji legalnych (sensu stricto) o charakterze cząstkowym.

Wskazane $\mathrm{w}$ omawianym paragrafie wzory nie sa jednak jedynymi dopuszczalnymi sposobami redagowania definicji - wyraża to użyty w przepisie zwrot „w szczególności”. Nie ma zakazu kształtowania definicji w sposób odmienny, nie ma więc zakazu formułowania innych jeszcze definicji równościowych, czastkowych nieprzyjmujących formy ostatniej ze wskazanych stylizacji, a także innych definicji nierównościowych.

Choć § 153 ZTP odnosi się wprost do definicji zakresowych, pogłębione rozważania na ich temat prowadzą do definicji cząstkowych. Przepis ów, choć wyraźnie preferuje definicje zakresowe pełne (będące definicjami równościowymi), dopuszcza możliwość wprowadzania definicji zakresowych niepełnych. Definicje takie stanowią więc przykład definicji cząstkowych.

W przypadku posłużenia się definicją niepełną należy jednocześnie wskazać, gdzie w systemie prawa znajduja się elementy uzupełniające tę definicję (§ 153 ust. 2 ZTP). Sławomira Wronkowska i Maciej Zieliński w Komentarzu do Zasad techniki prawodawczej zwracają uwagę na takie elementy, nazywajac je definicjami czastkowymi ${ }^{50}$. Te definicje cząstkowe moga więc uzupełniać zakres wzmiankowanych definicji niepełnych (będących również definicjami cząstkowymi i występujących w systemie jako definicje legalne sensu stricto), stanowiąc w takiej sytuacji tzw. modyfikatory ${ }^{51}$.

Ustęp trzeci powołanego paragrafu dopuszcza natomiast posłużenie się definicją niepełną także w przypadku, gdy brak jest w systemie prawa elementów ją dopełniajacych. Jest to jednak możliwe tylko w sytuacji, gdy utworzenie definicji legalnej nie jest możliwe w formie przewidzianej w poprzednich ustępach owego paragrafu.

Analiza ZTP prowadzi do wniosków, że prawodawca, nie wykluczając innych form definicji legalnych, preferuje postać równościową. Znajduje to uzasadnienie w postulowanych cechach prawa i języka prawnego - ich zrozumiałości i jednoznaczności. Zastosowanie więc w tekstach aktów prawnych definicji nierównościowych jest uzasadnione i poprawne, jeśli tylko zastosowanie takich definicji nie naruszy w pełni wzmiankowanych cech.

${ }^{47} \S 151$ ust. 2 ZTP.

48 S. Wronkowska, M. Zieliński, Komentarz do Zasad techniki prawodawczej, Wydawnictwo Sejmowe, Warszawa 2012, s. 283.

${ }_{49}$ Por. $§ 153$ ust. 3 ZTP.

50 S. Wronkowska, M. Zieliński, op. cit., s. 291.

51 Por. następną część niniejszego punktu. 


\section{Definicje legalne i definicje cząstkowe w teorii prawa}

Nie ma chyba wątpliwości, że na sposób rozumienia pojęcia definicji legalnej ogromny wpływ mają przyjęte założenia teoretycznoprawne. Odwołując się do założeń poznańsko-szczecińskiej szkoły teorii prawa, a także do derywacyjnej koncepcji wykładni prawa Zielińskiego, definicja legalna może pełnić funkcję zarówno normy, jak i dyrektywy wykładni.

Normatywność tekstów aktów prawnych, będąca fundamentem przyjmowanych koncepcji, przesądza o tym, że każdy element tekstu prawego - a więc także umieszczona tam definicja - ma charakter normatywny, to znaczy zawiera co najmniej fragment jednej normy prawnej. Ziembiński pisze: „Prawodawca, gdy formułuje definicję, pozostaje nadal normodawca w tym momencie. Tak bowiem, jak z każdą normą nakazującą sprzężona jest domyślnie norma generalnego nakazu zabraniająca wszystkiego, co mogłoby uniemożliwić wykonanie czynu nakazanego, tak z każdą sprzęga się też domyślnie norma wtórna, sformułowana w języku drugiego stopnia, która każe interpretować wyrażenia zawarte w normie podstawowej w taki sposób, w jaki (mówiąc w uproszczeniu) interpretowała te wyrażenia osoba, co stanowiła normę. Gdy są wątpliwości co do tego, jak należy rozumieć pewien zwrot ustawowy, owa normę wtórną należy sformułować expressis verbis, definiując, jak dane wyrażenie należy rozumieć" 52 .

Istnieją jednak poglądy odmienne od powyższego. Jan Gregorowicz wskazuje, że niewystarczajace jest według niego przedstawiony przez Zygmunta Ziembińskego argument dotyczący momentu stanowienia (prawodawca formułuje definicje jako podmiot władczy). Uważa ponadto, że Ziembiński miesza normy i reguły interpretacyjne, stąd też Gregorowicz stanowczo odmawia definicjom charakteru normatywnego.

Wydaje się, że krytyka Gregorowicza nie jest trafna. Moment stanowienia jest istotnym argumentem za uznaniem definicji za normę. Jest bowiem tak, że słowom normodawcy przypisujemy szczególną wagę, i nie ma powodu, dla którego mielibyśmy odmawiać tego kwalifikowanego charakteru definicjom. Niekategoryczna forma zdania, w postaci którego występuje definicja, również nie ma znaczenia dla jej normatywnego charakteru. Sam Gregorowicz staje na stanowisku, że odróżnienie elementów normatywnych od nienormatywnych (za które uważa definicje) nie zależy od użytych środków technicznych ${ }^{53}$.

Odpowiadając na zarzut mieszania norm i reguł interpretacyjnych, należy wskazać, że definicje legalne istotnie stanowią reguły interpretacyjne, dlatego są nazywane normami szczególnego rodzaju. Ta ich podwójna rola nie powoduje jednak utraty charakteru normatywnego ${ }^{54}$.

${ }^{52}$ Z. Ziembiński, op. cit., s. 61.

${ }^{53}$ J. Gregorowicz, Definicje w prawie i nauce prawa, Zakład Narodowy im. Ossolińskich we Wrocławiu, Łódź 1962, s. 51.

${ }_{54}$ M. Zieliński, Wykładnia prawa. Zasady - reguty - wskazówki, Wolters Kluwer, Warszawa 2017, s. 189-190. 
Definicje legalne sa niezwykle silnymi dyrektywami wykładni ${ }^{55}$. Po pierwsze dlatego, że powoduja konieczność odwrócenia czynności interpretacyjnych - podczas przeprowadzania wykładni najpierw należy poszukiwać znaczenia określonego terminu w tekście prawnym ujętego $\mathrm{w}$ definicję legalna, potem dopiero poszukiwać jego znaczenia w języku powszechnym ${ }^{56}$; po drugie zaś dlatego, że - jeśli definicja jest jednoznaczna językowo - nie można przełamać jej znaczenia, nawet w sytuacji, gdyby stała w sprzeczności z założeniem o racjonalności ustawodawcy ${ }^{57}$.

Ziembiński wskazuje sytuacje, w których potrzebna jest definicja ustawowa. Może to być z jednej strony okoliczność wprowadzenia przez ustawodawcę nowego pojęcia, z drugiej zaś - chęć usunięcia bądź ograniczenia nieostrości zwrotów zaczerpniętych z języka potocznego ${ }^{58}$. Ziembiński odnosi się do ograniczenia nieostrości, a więc dostrzega, że jest ona czasem pożądana, wiąże to jednak jedynie $\mathrm{z}$ ograniczeniem istniejącej nieostrości, nie wskazuje na możliwość wprowadzenia za pomocą definicji cząstkowej pojęć cechujących się taka nieostrościa ${ }^{59}$. Wydaje się, że nie ma przeszkód, aby ustawodawca nie tylko pozostawiał nieostrość niektórych zwrotów (definicja sensu largo), ale kreował ją za pomocą definicji cząstkowych (sensu stricto).

W koncepcji wykładni prawa Zieliński wyraźnie podkreśla przyczyny i cel umieszczania w tekstach prawnych definicji czastkowych. Przede wszystkim jest to zwiazane z potrzebą nadania tekstom aktów prawnych pewnej elastyczności, która umożliwia organom stosującym prawo dostosowanie swoich decyzji do indywidualnych cech określonej sytuacji ${ }^{60}$. Elastyczność taką uzyskuje się przez wprowadzanie do przepisu pojęć nieostrych. Gdy prawodawca decyduje się na zdefiniowanie takiego pojęcia i jednocześnie nie chce utracić całej jego nieostrości, będzie musiał posłużyć się definicja cząstkowa.

Inna przyczyną występowania definicji cząstkowych w systemie prawa jest stosowany niekiedy przez prawodawcę zabieg tzw. rozczłonkowania norm w przepisach prawnych. Zabieg ten polega na umieszczeniu fragmentów określonych norm w różnych przepisach prawnych i służy osiagnięciu skrótowości tekstów prawnych. Zieliński wskazuje na dwa stosowane przez prawodawcę sposoby rozczłonkowania norm w przepisach - rozczłonkowanie syntaktyczne i rozczłonkowanie treściowe ${ }^{61}$.

Kwestia rozczłonkowania syntaktycznego nie ma doniosłego znaczenia dla rozważań niniejszego artykułu, ponieważ powodować będzie jedynie oddalenie od siebie w tekście prawnym niektórych wyrażeń, które składają się na

${ }^{55}$ Ibidem, S. 190.

${ }^{56}$ Ibidem, s. $190-191$.

${ }^{57}$ Ibidem, s. 191.

${ }^{58}$ Warto wskazać na podobieństwa pomiędzy tezą Ziembińskiego a kształtem § 146 ZTP teza owa została przecież sformułowana na wiele lat przed wydaniem rozporządzania, którego ZTP stanowia załącznik. Z. Ziembiński, op. cit., s. 63-64.

${ }^{59}$ Ibidem, s. 64.

${ }^{60}$ M. Zieliński, op. cit., s. 160-161.

${ }^{61}$ Ibidem, s. 101. 
definicję legalną sensu largo określonego pojęcia. Aby w pełni odtworzyć taka definicję i tak należy odnieść się do całości systemu prawa. Dużo bardziej interesująca w kontekście rozważanych zagadnień będzie problematyka drugiego z wyróżnionych rodzajów rozczłonkowania norm.

Rozczłonkowanie treściowe norm w przepisach prawnych polega na podziale i umieszczeniu w różnych przepisach prawnych elementów treści danej normy. W przypadku zastosowania takiej techniki rozczłonkowania modyfikacji moga podlegać poszczególne elementy normy - objawia się pełne spektrum możliwości dzielenia treści normy, czego konsekwencją będzie występowanie w systemie prawa rozstrzelonych definicji cząstkowych określonego pojęcia. Dotyczy to nie tylko definicji legalnych sensu largo, ale także definicji legalnych sensu stricto, jeśli akurat taka definicja w modyfikowanym przepisie centralnym występuje. Definicja odtworzona na podstawie przepisu centralnego i modyfikatorów może już w pełni określać zakres definiowanego pojęcia, może być również tak, że definicja złożona z kilku definicji cząstkowych nadal pozostanie cząstkowa.

\section{PODSUMOWANIE}

Zachowanie formy cząstkowej w niektórych sytuacjach konieczne jest do utrzymania poprawności definicji, ponieważ tylko definicje cząstkowe dają możliwość wprowadzania terminów dyspozycyjnych. Ich wprowadzanie za pomocą definicji równościowych prowadzi do nieadekwatności definicji - ich zbyt szerokiego lub wasskiego zakresu. Definicje cząstkowe nie powinny być więc traktowane w żadnym wypadku jako „gorsze” od definicji w pełni określających zakres definiowanych pojęć. Należy mieć świadomość, że służą one do innych celów. Zdefiniowanie pojęcia dyspozycyjnego za pomocą definicji równościowej jest takim samym błędem, jak niezamierzone nieobjęcie zakresem definicji jakichś elementów wchodzących w zakres definiowanego pojęcia. Prawodawca często posługuje się pojęciami otwartymi i nieostrymi - mają one doniosłe znaczenie w systemie prawa. Ze względu na powiązanie takich pojęć z formą definicji cząstkowych należy wskazać na równie doniosłe znaczenie tych ostatnich oraz ich powszechność w systemie prawa (zarówno jako definicji legalnych sensu stricto, jak i definicji legalnych sensu largo). W związku z tym wydaje się, że doktryna prawnicza powinna zagadnieniu definicji cząstkowych zaczaćc przypisywać odpowiednią wagę.

mgr Kamila Kosińska

Uniwersytet im. Adama Mickiewicza w Poznaniu

kamila.kosinska@op.pl

https://orcid.org/0000-0002-4192-1813 


\section{PARTIAL DEFINITIONS IN LAW}

\section{Summary}

The aim of the article was to determine the forms in which partial definitions appear in the texts of legislative acts and to search for other possible forms of their application. Rudolf Carnap's concept of the inadequacy of equality definitions when attempting to define disposable concepts was analysed. The article contains reflections on the contemporary views on the formulation of definitions or providing definitions in the texts of legislative acts and on the rules contained in the principles of legislative technique applicable to the subject matter of this study. A possibility of using partial definitions as legal definitions has been shown and a postulate to stimulate a discussion on the possibility of introducing into legal texts definitions other than equality definitions has been formulated. 